\title{
A Review of the Literature Evaluating Adherence and Persistence to Adjuvant Endocrine Therapy
}

\author{
Strickland KS*, Barsevick A, Abu-Khalaf MM \\ Department of Medical Oncology, Sidney Kimmel Cancer Center at Thomas Jefferson University, USA
}

Submission: December 06, 2017 ; Published: December 20, 2017

*Corresponding author: Kimberly Strickland, Department of Medical Oncology, Sidney Kimmel Cancer Center at Thomas Jefferson University, USA, Email: Kimberly.Strickland@jefferson.edu

\section{Mini Review}

The use of adjuvant endocrine therapy (ET, e.g. tamoxifen or aromatase inhibitors: anastrozole, letrozole, exemestine) for five to ten years is the standard of care for individuals with hormone receptor positive breast cancer [1]. ET has resulted in impressive reductions in disease recurrence and mortality [2]. When taken as prescribed, these agents can reduce recurrence by $30-50 \%$ and reduce mortality by approximately one third irrespective of treatment with chemotherapy $[2,3]$. As evidence of the survival advantage of ET has mounted, taking the drug daily as directed (adherence) and continuing treatment as prescribed for 5-10 years (persistence) have emerged as potential contributors to differences in therapeutic effect. Adherence to the correct daily dose of ET becomes more problematic over the expected five or more years of treatment, ranging from $79.6 \%$ after year 1 to $68.3 \%$ after year 5 . Persistence across the 5 -year period is also problematic ranging from $13.6 \%$ in year 1 to $40.9 \%$ in year 5 [4].

Adherence is defined as the degree of conformity to provider prescription with regard to timing, dosage, and frequency of day-to-day medication use. It has been operationalized in adjuvant breast clinical trials as having possession of a supply of medication to cover $80 \%$ or more days over a given time period [5]. In a systematic review of 29 adjuvant ET adherence studies, Murphy showed that adherence to ET in clinical practice settings ranged from $41-72 \%$. Adherence was slightly higher among those receiving aromatase inhibitors (50-91\%) versus tamoxifen (41-88\%). This was somewhat lower than previous retrospective analyses of clinical trials data in which adherence was higher, $50-90 \%$, raising the concern that adherence rates observed in clinical trials may not represent a real-life setting.

The reasons for non-adherence or non-persistence of ET are not entirely clear, but there is evidence that side effects such as hot flashes, joint aches and stiffness may contribute a great deal [5-7]. In the Mammary Prevention [3] (MAP.3) breast cancer prevention trial, it was noted that patients with negative changes in the menopausal specific quality of life questionnaire had early rates of treatment discontinuation [8]. Additionally, it demonstrated that non adherent breast cancer survivors expressed more difficulty managing side effects and perceived fewer benefits when side effects were bothersome [9]. Persistence refers to the duration from initiation to discontinuation of therapy. It has been operationalized variously as no more than 45,90 , or 180 days elapsed without prescription renewal. A retrospective evaluation of prescription fills showed that the median duration of tamoxifen therapy was 2.42 years with $51 \%$ discontinuing before 5 years.

In a large review by Murphy et al., it was noted that extremes of age (i.e. younger or older), increasing out-of-pocket costs, follow up care with general practitioner (vs. oncologist), and side effects were all mainly negatively associated with adherence [1025]. On the flip side, it was found that taking more medications at baseline, referral to an oncologist, and earlier age at diagnosis were mostly associated with adherence or persistence [10,11,14,19,26-28]. Furthermore, patients that switched from tamoxifen to an aromatase inhibitor after 2-3 years were less likely to be adherent $[10,11,26]$.

Only a few interventions to improve adherence have been evaluated in the setting of adjuvant ET. There is evidence in the clinical trial setting of higher adherence and duration of therapy, suggesting that increased contact from health care providers could be of benefit [29]. Research has shown that educational materials and reminders did not increase adherence to ET [2931]. Two randomized trials that compared educational materials about ET with standard care showed no difference in adherence after 1 year [29,32]. Another intervention trial with a small sample compared standard care versus mailings ( 5 letters year 1 and 3 letters year 2) versus telephone calls (5 calls year 1; 3 calls year 2) to improve adherence to aromatase inhibitors [31].

Although the three intervention groups did not differ, a pooled analysis comparing both interventions with standard care showed that frequent contact was superior to standard care. 
Another study evaluated the use of standard of care to standard of care plus a patient support group. Results of this study showed 1 -year persistence rates of nearly $96 \%$ in both groups, but no difference between the two arms [33]. No intervention studies focused on management of ET-related symptoms as a means of improving adherence to therapy. Given that side effects may contribute to discontinuation or issues with adherence, methods to improve upon the most common side effects can be implemented [5-7]. For example, both serotonin and norepinephrine reuptake inhibitors (SNRIs, e.g. venlafaxine) and selective serotonin reuptake inhibitors (SSRIs, e.g. fluoxetine) have been shown to decrease the amount of vasomotor symptoms such as hot flashes that patients experience [34,35].

For arthralgia complaints, there is a lack of effective treatment options, but patients may find benefit from non-steroidal antiinflammatory drugs (NSAIDs), exercise, and/or weight loss [36]. Interestingly, the only intervention for which there is prospective, randomized data to support its use in aromatase inhibitor associated arthralgia is acupuncture [37]. Vaginal dryness and sexual dysfunction are common complaints [38]. For dryness, water based lubricants are usually recommended [36]. Even though topical estrogens are occasionally recommended in severe cases, there is concern for systemic absorption which could lead to an increased risk of breast cancer recurrence. Although data from large randomized trials is lacking, studies of small patient cohorts suggest that the use of topical estrogens may not increase the risk of recurrence [39].

The American College of Obstetricians and Gynecologists recommend that among women with a history of estrogendependent breast cancer who are experiencing urogenital symptoms, vaginal estrogen should be reserved for those patients who are unresponsive to non-hormonal remedies [40]. They conclude that treatment should be individualized based on each woman's risk-benefit ratio and clinical presentation. Currently, there is no standard approach to ensure that patients remain adherent to ET. Ongoing studies continue to evaluate various methods in which to address barriers to oral therapy adherence. It is likely that a personalized approach may be needed as the reasons in which patients tend to be non-adherence are not universal amongst all patients taking adjuvant endocrine therapy. Furthermore, clinical trials have shown that physician reporting of symptoms is neither sensitive nor specific, but that patient reported outcome measures have increased levels of sensitivity and can improve quality of life and overall survival in certain settings $[41,42]$. Therefore, it may also be of benefit to use patient-reported outcomes to closely monitor ET related adverse symptoms. As practitioners, we must continuously evaluating patient adherence to oral therapy and address any barriers to adherence and persistence such as side effects, costs and patient understanding of the importance of maintaining adequate adherence to such therapies. In particular, close attention to modifiable risk factors for non-adherence and non-persistence such as side effects is of the upmost importance.

\section{References}

1. National Comprehensive Cancer Network. Breast Cancer.

2. EBCTCG Early Breast Cancer Trialists Collaborative Group, (2005) Effect of chemotherapy and hormonal therapy for early breast cancer on recurrence and 15-year survival: an overview of randomized trials. Lancet 365: 1687-1717.

3. Davies C, Godwin J, Gray R, Clarke M, Cutter D, et al. (2011) Relevance of breast cancer hormone receptors and other factors to the efficacy of adjuvant tamoxifen: patient-level meta-analysis of randomised trials. Lancet 378(9793): 771-784.

4. Huiart L, Ferdynus C, Giorgi R (2013) A meta-regression analysis of the available data on adherence to adjuvant hormonal therapy in breast cancer: summarizing the data for clinicians. Breast Cancer Res. Treat 138(1): 325-328.

5. Partridge AH, Wang PS, Winer EP, Avorn J (2003) Nonadherence to adjuvant tamoxifen therapy in women with primary breast cancer. J Clin Oncol 21(4): 602-606.

6. Crew KD, Capodice JL, Greenlee H, Apollo A, Jacobson J, et al. (2007) Piolt study of acupuncture for the treatment of joint symptoms related to adjuvant aromatase inhibitor therapy in postmenopausal breast cancer patients. J Cancer Surviv 1(4): 283-291.

7. Rosenberg SM, Stanton AL, Petrie KJ, Partridge AH (2015) Symptoms and Symptom Attribution Among Women on Endocrine Therapy for Breast Cancer. Oncologist 20(6): 598-604.

8. Meggetto O, Maunsell E, Chelbowski R, Goss P, Tu D, et al. (2017) Factors Associated with Early Discontinuation of Study Treatment in the Mammary Prevention.3 Breast Cancer Chemoprevention Trial. J Clin Oncol 35(6): 629-635.

9. Bluethmann SM, Murphy CC, Tiro JA, , Mollica MA, Vernon SW, et al. (2017) Deconstructing Decisions to Initiate, Maintain, or Discontinue Adjuvant Endocrine Therapy in Breast Cancer Survivors: A MixedMethods Study. Oncology Nursing Forum 44(3): E101-E110.

10. Murphy CC, Bartholomew LK, Carpentier MY, Bluethmann SM, Vernon SW (2012) Adherence to adjuvant hormonal therapy among breast cancer survivors in clinical practice: a systematic review. Breast Cancer Res Treat 134(2): 459-478.

11. Sedjo RL, Devine S (2011) Predictors of non-adherence to aromatase inhibitors among commercially insured women with breast cancer. Breast Cancer Res Treat 125(1): 191-200.

12. McCowan C, Shearer J, Donnan PT, Dewar JA, Crilly M, et al. (2008) Cohort study examining tamoxifen adherence and its relationship to mortality in women with breast cancer. Br J Cancer 99(11): 1763-1768.

13. Banning M (2012) Adherence to adjuvant therapy in post-menopausal breast cancer patients: a review. Eur J Cancer Care 21(1): 10-19.

14. Partridge AH, LaFountain A, Mayer E, Taylor BS, Winer E, et al. (2008) Adherence to initial anastrozole therapy among women with earlystage breast cancer. J Clin Oncol 26(4): 556-562.

15. Hershman DL, Kushi LH, Shao T, Buono D, Kershenbaum A, et al. (2010) Early discontinuation and nonadherence to adjuvant hormonal therapy in a cohort of 8,769 early-stage breast cancer patients. J Clin Oncol 28(27): 4120-4128.

16. Crevellari D, Sun Z, Coates A, Price KN, Thürlimann B, et al. (2008) Letrozole compared with tamoxifen for elderly patients with endocrine-responsive early breast cancer: the BIG 1-98 trial. J Clin Oncol 26(12): 1972-1979.

17. Schroth W, Goetz MP, Hamann U, Fasching PA, Schmidt M, et al. (2009) Association between CYP2D6 polymorphisms and outcomes among women with early breast cancer treated with tamoxifen. JAMA 302(13): 1429-1436. 
18. Rae JM, Sikora MJ, Henry NL, Li L, Kim S, et al. (2009) Cytochrome P450 2D6 activity predicts discontinuation of tamoxifen therapy in breast cancer patients. Pharmacogenomics J 9(4): 258-264.

19. Sehdev S, Martin G, Sideris L, Lam W, Brisson S (2009) Safety of adjuvant endocrine therapies in hormone receptor-positive early breast cancer. Curr Oncol 16(Suppl 2): S14-S23.

20. Bertelli G, Hall E, Ireland E, Snowdon CF, Jassem J, et al. (2010) Longterm endometrial effects in postmenopausal women with early breast cancer participation in the Intergroup Exemestane Study (IES) a randomised controlled trial of exemestane versus continue tamoxifen after 2-3 years tamoxifen. Ann Oncol 21(3): 498-505.

21. Marsden JO (2002) Hormone-replacement therapy and breast cancer Lancet Oncol 3(5): 303-311.

22. Wengström $Y$ (2008) Effectively nursing patients receiving aromatase inhibitor therapy. Breast 17(3): 227-238.

23. Carson JW, Carson KW, Porter LS, Keefe FJ, Seewaldt VL (2009) Yoga of Awareness program for menopausal symptoms in breast cancer survivors: results from a randomized trial. Support Care Cancer 17(10): 1301-1309.

24. Markopoulos G, Tzoracoleftherakis E, Polyschronis A, Venizelos B, Dafni U, et al. (2010) Management of anastrozole-induced bone loss in breast cancer with oral risedronate: results from the ARBI prospective clinical trial. Breast Cancer Res 12(2): R24.

25. Penning-van Beest FJ, Goettsch WG, Erkens JA, Herrings RM (2006) Determinants of persistence with bisphosphonates-a study in women with postmenopausal osteoporosis. Clin Ther 28(2): 236-242.

26. Wigertz A, Ahlgren J, Holmqvist M, Fornander T, Adolfsson J, et al. (2012) Adherence and discontinuation of adjuvant hormonal therapy in breast cancer patients: a population-based study. Breast Cancer Res Treat 133(1): 367-373.

27. Fink AK, Gurwitz J, Rakowski W, Guadagnoli E, Silliman RA (2004) Patient beliefs and tamoxifen discontinuance in older women with estrogen receptor-positive breast cancer. J Clin Oncol 22(16): 33093315.

28. Nekhlyudov L, Lingling L, Ross-Degnan D, Wagner AK (2011) Five-year patterns of adjuvant hormonal therapy use, persistence, and adherence among insured women with early-stage breast cancer. Breast Cancer Res Treat 130(2): 681-689.

29. Neven P, Markopoulos C, Tanner M, Marty M, Kreienberg R, et al. (2014) The impact of educational materials on compliance and persistence rates with adjuvant aromatase inhibitor treatment: first-year results from the compliance of aromatase inhibitors assessment in daily practice through educational approach (CARIATIDE) study. Breast 23(4): 393-399.

30. Hadji P, Blettner M, Harbeck N, Jackisch C, Lück HJ, et al. (2013) The Patient's Anastrozole Compliance to Therapy (PACT) Program: a randomized, in-practice study on the impact of a standardized information program on persistence and compliance to adjuvant endocrine therapy in postmenopausal women with early breast cancer Ann Oncol 24(6): 1505-1512.
31. Ziller V, Kyvernitakis I, Knoll D, Storch A, Hars O, Hadji P (2013) Influence of a patient information program on adherence and persistence with an aromatase inhibitor in breast cancer treatment--the COMPAS study. BMC Cancer 13: 407.

32. Harbeck N, Blettner M, Hadji P, Jackisch C, Lück HJ, etal. (2013) Patient's Anastrozole Compliance to Therapy (PACT) Program: Baseline Data and Patient Characteristics from a Population-Based, Randomized Study Evaluating Compliance to Aromatase Inhibitor Therapy in Postmenopausal Women with Hormone-Sensitive Early Breast Cancer. Breast Care (Basel) 8(2): 110-120.

33. Yu KD, Zhou Y, Liu GY, Li B, He PQ et al. (2012) A prospective, multicenter, controlled, observational study to evaluate the efficiacy of a patient support program in improving patients' persistance to adjuvant aromatase inhibitor medication for postmenopausal, early stage breast cancer. Breast Cancer Res Treat 134(1): 307-313.

34. Loprinzi CL, Kugler JW, Sloan JA, Mailliard JA, LaVasseur BI, et al. (2000) Venlafaxine in management of hot flashes in survivors of breast cancer: a randomised controlled trial. Lancet 356(9247): 2059-2063.

35. Loprinzi CL, Sloan JA, Perez EA, Quella SK, Stella PJ, et al. (2002) Phase III evaluation of fluoxetine for treatment of hot flashes. J ClinOncol 20(6):1578-1583.

36. Niravath P (2013) Aromatase inhibitor-induced arthralgia: a review. Ann Oncol 24(6): 1443-1449.

37. Crew K, Capodice J, Greenlee H, Brafman L, Fuentes D, et al. (2010) Randomized, blinded, sham-controlled trial of acupuncture for the management of AI associated joint symptoms in women with early stage breast cancer. J Clin Oncol 28(7): 1154-1160.

38. Fallowfield L, Cella D, Cuzick J, Francis S, Locker G, et al. (2004) Quality of life of postmenopausal women in the Arimidex, Tamoxifen, Alone or in Combination (ATAC) adjuvant breast cancer trial. J Clin Oncol 22(21): 4261-4271.

39. Le Ray I, Dell'Aniello S, Bonnetain F, Azoulay L, Suissa S (2012) Local estrogen therapy and risk of breast cancer recurrecnce among hormone-treated patients: a nested case-control study. Breast Cancer Res Treat 135(2): 603-609.

40. American College of Obstetricians and Gynecologists Committee Opinion No. 659 (2016) The use of vaginal estrogen in women with a history of estrogen-dependent breast cancer. ObstetGynecol 127: e93-e96.

41. Fromme EK, Eilers KM, Mori M, , Hsieh YC, Beer TM (2004) How Accurate is Clinician Reporting of Chemotherapy Adverse Effects? A Comparison with Patient-Reported Symptoms Fromthe Quality-of-Life Questionnaire C30. J Clin Oncol 22(17): 3485-3490.

42. Basch E, Deal AM, Dueck AC, Scher HI, Kris MG, et al. (2017) Overall Survival Results of a Trial Assessing Patient-Reported Outcomes for Symptom Monitoring During Routine Cancer Treatment. JAMA 318(2): 197-198. 
This work is licensed under Creative Commons Attribution 4.0 Licens

DOI: 10.19080/JGWH.2017.07.555725
Your next submission with Juniper Publishers will reach you the below assets

- Quality Editorial service

- Swift Peer Review

- Reprints availability

- E-prints Service

- Manuscript Podcast for convenient understanding

- Global attainment for your research

- Manuscript accessibility in different formats

( Pdf, E-pub, Full Text, Audio)

- Unceasing customer service

Track the below URL for one-step submission https://juniperpublishers.com/online-submission.php 